\title{
Gentamicin extraction from an anuric patient by combined haemodialysis and charcoal haemoperfusion
}

\author{
N. WRIGHT* \\ B.Sc., M.B., Ch.B., F.R.C.P.(Ed.) \\ A. BhamjeE $\uparrow$ \\ L.R.C.P. \\ *Regional Poisoning Treatment Centre, and †Department of Medical Microbiology, \\ Dudley Road Hospital, Birmingham B18 $7 \mathrm{QH}$
}

\begin{abstract}
Summary
A 39-year-old woman who developed acute renal failure following intra-abdominal sepsis was treated with gentamicin. Her serum concentrations reached potentially toxic levels. Combined haemoperfusion and haemodialysis removed approximately $\mathbf{7 0} \%$ of the given drug and the patient made a complete recovery.
\end{abstract}

\section{Introduction}

Gentamicin has been noted by Avery (1976) to have a narrow therapeutic range and that toxicity is particularly associated with renal dysfunction. It can be removed by haemodialysis. Christopher $e t$ al. (1974) reported a clearance of $24 \mathrm{ml} / \mathrm{min}$ equivalent to a half-life of $10 \cdot 1 \mathrm{hr}$ and Lockwood (1973) a clearance of $42 \mathrm{ml} / \mathrm{min}$ equivalent to $6 \cdot 1 \mathrm{hr}$. These differences may be due partly to variations in technique and blood flow rate.

The present authors report a more rapid reduction in plasma concentration by combined haemoperfusion through acrylic resin-coated charcoal and haemodialysis in an anuric patient who had received excessive quantities of the drug.

\section{Case Report}

A 39-year-old woman was admitted with a 24-hr history of abdominal pain, fever and rigors. Laparotomy was performed and a grossly infected pyosalpinx was removed. Initially her postoperative course was normal. However, $18 \mathrm{hr}$ later she collapsed and became hypotensive. Streptococcus pyogenes was isolated $48 \mathrm{hr}$ later from blood cultures taken at the time of collapse. In the interim she was started on gentamicin as a Gram-negative septicaemia was feared. After receiving a total of $540 \mathrm{mg}$ she became anuric and was given frusemide; $24 \mathrm{hr}$ later the gentamicin level was $15.6 \mathrm{mg} / \mathrm{l}$, falling to $15.3 \mathrm{mg} / \mathrm{ml} 12 \mathrm{hr}$ later. Gentamicin was measured by the acetyltransferase method reported by Broughall and Reeves (1975). A Scribner shunt was then inserted and combined haemoperfusion and haemodialysis using a charcoal column and an RSP haemodialyser was performed for a 6 -hr period. ज़ Blood was passed from the radial artery to the column, on the coil, and back to the patient. Blood N flow was measured by bubble transit times. Serial $\vec{A}$ blood concentrations were obtained. Gentamicin ${ }^{\circ}$ concentration differences across the column and $\frac{\text { }}{2}$ coil are shown in Fig. 1. The amount of drug -

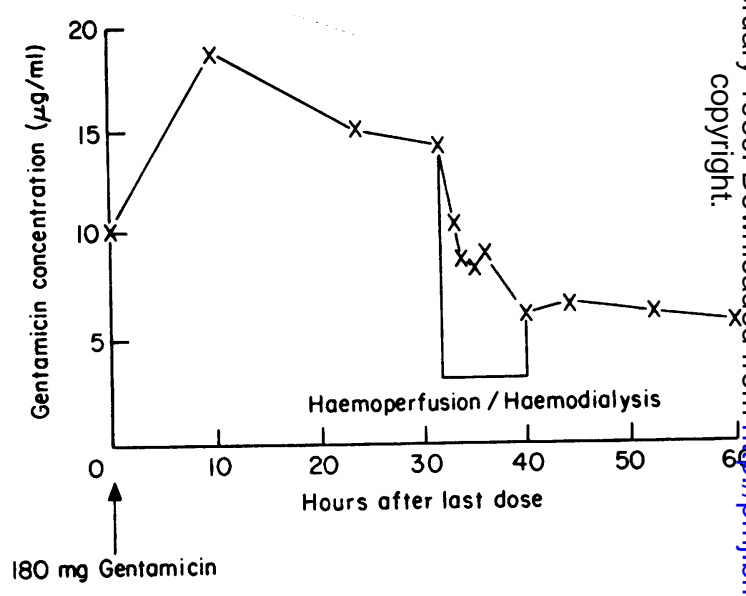

FIG. 1. Serial gentamicin concentration in a patient undergoing combined haemodialysis and haemoperfusion.

removed was calculated (Table 1). In all, $402 \cdot 7 \mathrm{mg}$ 要 were removed: $206.6 \mathrm{mg}$ were taken up by the column, of which $76 \%$ came out during the first $3 \mathrm{hr}, \stackrel{N}{\sim}$ and $196.1 \mathrm{mg}$ were removed by dialysis (Fig. 2).

At the end of dialysis and haemoperfusion the gentamicin concentration had fallen from $15 \cdot 1 \mathrm{mg} / \mathrm{l}_{\sigma}^{\omega}$ to $5 \cdot 1 \mathrm{mg} / \mathrm{l}$. This was equivalent to a gentamicin half-life of $3.4 \mathrm{hr}$. It later rose to a peak of $5.9 \mathrm{mg} / 100$ $\mathrm{ml}$ after equilibration. Platelets fell from $210 \times 10^{9} /{ }^{\infty}$ to $132 \times 10^{9} / 1$. Seven days later the patient entered the diuretic phase and then recovered completely. 
TABLE 1. Serial gentamicin levels during combined haemoperfusion and haemodialysis

\begin{tabular}{|c|c|c|c|c|c|}
\hline $\begin{array}{l}\text { Time after } \\
\text { start of } \\
\text { perfusion } \\
\text { (hr) }\end{array}$ & $\begin{array}{l}\text { Patient } \\
\text { gentamicin } \\
(\mathrm{mg} / \mathrm{l})\end{array}$ & $\begin{array}{l}\text { Post-column } \\
\text { pre-coil } \\
\text { gentamicin } \\
(\mathrm{mg} / \mathrm{l})\end{array}$ & $\begin{array}{l}\text { Post-column } \\
\text { and coil } \\
\text { gentamicin } \\
(\mathrm{mg} / \mathrm{l})\end{array}$ & $\begin{array}{l}\text { Amount gentamicin } \\
\text { removed by column } \\
\text { (mg) }\end{array}$ & $\begin{array}{l}\text { Amount gentamicin } \\
\text { removed by coil } \\
(\mathrm{mg})\end{array}$ \\
\hline 0.5 & $15 \cdot 1$ & $6 \cdot 5$ & $3 \cdot 1$ & $92 \cdot 9$ & $36 \cdot 7$ \\
\hline 1.5 & $10 \cdot 5$ & 5.9 & $3 \cdot 3$ & $49 \cdot 7$ & $28 \cdot 1$ \\
\hline $2 \cdot 5$ & 8.9 & $7 \cdot 1$ & $3 \cdot 4$ & 18.0 & $37 \cdot 0$ \\
\hline $3 \cdot 5$ & $8 \cdot 5$ & $6 \cdot 7$ & 3.9 & $18 \cdot 0$ & $28 \cdot 0$ \\
\hline $4 \cdot 5$ & $9 \cdot 1$ & $7 \cdot 2$ & $3 \cdot 5$ & $17 \cdot 0$ & $40 \cdot 3$ \\
\hline $5 \cdot 5$ & $7 \cdot 2$ & $6 \cdot 0$ & $3 \cdot 1$ & $11 \cdot 0$ & $26 \cdot 0$ \\
\hline \multicolumn{4}{|c|}{ Total gentamicin removed } & $206 \cdot 6$ & $196 \cdot 1$ \\
\hline
\end{tabular}

Clinical and caloric testing of vestibular function did not reveal any evidence of damage.

\section{Discussion}

Gentamicin is a dangerous drug which may cause vestibular damage and, especially when associated with frusemide, can produce proximal tubular damage. It is hoped that it will be replaced by new penicillins or cephalosporins with similar antibacterial activity but less toxicity. At present, however, gentamicin is the drug of choice in some Gram-negative bacterial septicaemias. Acute renal

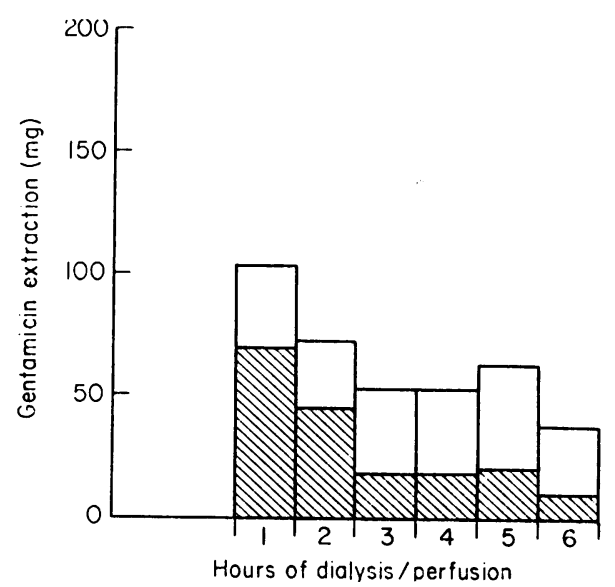

FIG. 2. Total gentamicin extraction during haemoperfusion and haemodialysis. Column extraction (mg), $\square$ coil extraction (mg). failure is a complication of septicaemia and, as gentamicin is excreted solely via the kidneys, cumulation is liable to occur. The above results show that gentamicin can be removed approximately twice as rapidly by combined haemoperfusion and haemodialysis as by haemodialysis alone. Similar extraction could have been attained by haemodialysis alone only if the procedure had continued for at least $12 \mathrm{hr}$. If the column had been changed at 3 $\mathrm{hr}$ an even better extraction rate would have been obtained. Gentamicin half-life in an anuric patient is $\mathbf{4 8} \mathrm{hr}$ or more, so it is likely that this patient would have sustained vestibular damage if active measures had not been taken to reduce blood concentrations. Whether the more rapid extraction attained by the combined procedure is necessary to protect against ototoxicity remains unproved. However, addition of the column to the dialysis circuit is simple and does not add to the technical complexities of the procedure.

\section{References}

Avery, G.S. (1976) Drug Treatment. Churchill Livingstone, Edinburgh and London.

Broughall, J.M. \& Reeves, D.S. (1975) The acetyltransferase enzyme method for the assay of serum gentamicin concentration and a comparison with other methods. Journal of Clinical Pathology, 28, 140.

Christopher, T.G., Korn, D., Blair, A.D., Forrey, A.W., O'NeILl, M.A. \& CuTler, R.E. (1974) Gentamicin pharmacokinetics during hemodialysis. Kidney International, 6, 38.

Lockwood, W.R. (1973) Tobramycin and gentamicin concentrations in the serum of normal and anephric patients. Antimicrobial Agents and Chemotherapy, 3, 125. 